University of Nebraska - Lincoln

DigitalCommons@University of Nebraska - Lincoln

Nebraska Game and Parks Commission -- Staff

Research Publications

Nebraska Game and Parks Commission

January 1980

\title{
Leslie Population Estimate for a Large Lake
}

Jack Peterson

Nebraska Game and Parks Commission

Melvin Taylor

Nebraska Game and Parks Commission

Allan Hanson

Nebraska Game and Parks Commission

Follow this and additional works at: https://digitalcommons.unl.edu/nebgamestaff

Part of the Environmental Sciences Commons

Peterson, Jack; Taylor, Melvin; and Hanson, Allan, "Leslie Population Estimate for a Large Lake" (1980). Nebraska Game and Parks Commission -- Staff Research Publications. 17.

https://digitalcommons.unl.edu/nebgamestaff/17

This Article is brought to you for free and open access by the Nebraska Game and Parks Commission at DigitalCommons@University of Nebraska - Lincoln. It has been accepted for inclusion in Nebraska Game and Parks Commission -- Staff Research Publications by an authorized administrator of DigitalCommons@University of Nebraska - Lincoln. 


\section{Leslie Population Estimate for a Large Lake}

\author{
Jack Peterson, Melvin Taylor, and Allan \\ HANSON
}

Nebraska Game and Parks Commission Lincoln, Nebraska 68503

\section{Abstract}

The accuracy of a population estimate made by the Leslie removal method was evaluated for adult northern pike (Esox lucius) in a 288-hectare lake. The Leslie estimate of 6,290 fish was within $1 \%$ of that obtained from direct enumeration.

Basically, the Leslie removal method of estimating population numbers involves the linear regression of catch per unit of effort against cumulative catch (Ricker 1975 and references therein). Extrapolated to zero catch per effort, this regression gives the original population size. For the method to be effective, several conditions should be met: (1) a significant proportion of the population must be removed, preferably in a short period of time; (2) recruitment and natural mortality must be negligible and the entire population must be available to the fishery throughout the removal period; (3) the catchability of the fish must remain constant during the sampling period; (4) the units of gear should not compete significantly with one another.

Although previously used in fishery investigations (Omand 1951; Von Geldern 1961; Johnson 1965), field verifications of the Leslie method are few. Hatcher (1962) confirmed its accuracy for channel catfish (Ictalurus punctatus) populations in farm ponds, but we have found no report of its verification for a large body of water. In this paper, we describe our test of the Leslie method for northern pike (Esox lucius) in a 288-hectare lake.

\section{Methods}

Island Lake is an internally draining sandhill lake (McCarraher 1977) located in Garden County, west-central Nebraska. It has an area of 288 hectares, a mean depth of $1.1 \mathrm{~m}$, and a maximum depth of $2.8 \mathrm{~m}$. Among other game fish stocked in the lake, northern pike were added in 1960 in an unsuccessful attempt to control carp (Cyprinus carpio). Turbid water conditions caused by the carp severely degraded the habitat for game fish and waterfowl, and a chemical elimination of the fish was scheduled for October 1978. Prior to this treatment as many adult northern pike as possible were removed from the lake and relocated. Removal necessarily occurred in March and April 1978, immediately prior to the spawning season when northern pike were most vulnerable to trapping. We used double-throated frame nets with $1.2 \times 9.2-\mathrm{m}$ leads and $16-\mathrm{mm}$ bar mesh throughout. Nets were placed at random around the shoreline, perpendicular to shore, lead end toward the bank. Ten nets were fished the first day, 14 the next day, and 15 for 7 days thereafter. From the resulting catch-effort data, we calculated the initial adult population size and confidence limits about the estimate (Ricker 1975) by the Leslie method. Our computer program for this exercise is available upon request.

To save on the cost of rotenone the lake was drawn down by pumping beginning in July 1978 , and was reduced to about one-fourth its original volume by October 24. Pumping was delayed until July for budgetary reasons. Pumps were operated almost continually from July to October. The remaining pool was treated with $2 \mathrm{mg} / \mathrm{liter}$ ProNoxfish (2.5\% rotenone) on October 24. The following day, all adult northern pike were counted from an air boat. Adults were distinguished from young of the year by size, young of the year being $200 \mathrm{~mm}$ in total length or less, age 1 or older being 350 $\mathrm{mm}$ or greater. No overlap in size occurred between age- 0 and age- 1 fish. To qualitatively assess the success of the renovation, gill nets were fished for 263 net nights in the spring and summer 1979. Population estimates made in the spring were then compared to the sum of fish removed in the spring and killed by rotenone to evaluate the accuracy of the Leslie procedure.

\section{Results and Discussion}

The frame nets caught 6,104 northern pike during the spring removal operation (Table 1). The relationship of catch per unit effort $\left(C_{t} / f_{t}\right)$ to cumulative catch $\left(K_{t}\right)$ over the 9 sampling days was $C_{t} / f_{t}=171.15-0.0272 K_{t} ; r=-0.97$; $P<0.01 . K_{t}$ is the sum of all catches prior to day $t$ plus one-half of the catch on day $t$ (Table 
TABLE 1.-Frame-net effort for northern pike, catch, and Leslie population estimates, Island Lake, Nebraska, 1978.

\begin{tabular}{lccccccc}
\hline $\begin{array}{l}\text { Sam- } \\
\text { pling } \\
\text { date }\end{array}$ & $\begin{array}{c}\text { Number } \\
\text { of nets }\end{array}$ & $\begin{array}{c}\text { Number } \\
\text { of fish } \\
\text { caught }\end{array}$ & $\begin{array}{c}\text { Catch per } \\
\text { net-day } \\
\left(C_{t}\left(f_{t}\right)\right.\end{array}$ & $\begin{array}{c}\text { Cumulative } \\
\text { catch }\left(K_{t}\right)\end{array}$ & $\begin{array}{c}\text { Leslie point } \\
\text { estimate }\end{array}$ & Lower & Upper \\
\hline Mar 28 & 10 & 1,561 & 156.1 & 780.5 & & & \\
Mar 29 & 14 & 1,260 & 90.0 & $2,191.0$ & & & \\
Mar 30 & 15 & 1,454 & 96.9 & $3,548.0$ & & & \\
Mar 31 & 15 & 634 & 42.3 & $4,592.0$ & 6,490 & 4,570 & 25,440 \\
Apr 1 & 15 & 514 & 34.3 & $5,166.0$ & 6,490 & 5,210 & 9,990 \\
Apr 2 & 15 & 240 & 16.0 & $5,543.0$ & 6,330 & 5,450 & 7,990 \\
Apr 3 & 15 & 161 & 10.7 & $5,743.5$ & 6,270 & 5,610 & 7,310 \\
Apr 4 & 15 & 146 & 9.7 & $5,897.0$ & 6,260 & 5,730 & 7,020 \\
Apr 5 & 15 & 134 & 8.9 & $6,037.0$ & 6,290 & 5,840 & 6,880 \\
\hline
\end{tabular}

a $K_{t}$ equals cumulative catch up to day $t$ plus one-half the catch on day $t$.

1). This equation gives a Leslie population estimate of 6,286 fish with $95 \%$ confidence limits of 5,841 and 6,884 .

The postrotenone count indicated a remaining population of 207 adult northern pike. If removal due to angling and natural mortality from March to October were minimal, the actual population size prior to removal was 6,311 , within $1 \%$ of the Leslie estimate.

Island Lake normally sustains very light fishing pressure and the low population present after spring trapping probably further discouraged angling. Personnel at the Crescent Lake National Waterfowl Refuge, which includes Island Lake, confirmed that fishing pressure was low; to their knowledge harvest was negligible. Adult northern pike have few enemies and under low population levels environmental stress was unlikely. We feel the assumptions of minimal natural and fishing mortalities are reasonable.

Normally, counting fish on only 1 day after a renovation results in biased results due to the sinking of dead fish and usual large number that must be counted. In this situation the water was very shallow and due to constant wave action, few, if any, fish remained on the bottom. Rafting of fish on one shore and the low number of northern pike present made counting easy. We feel it is a reasonable estimate of the remaining population.

Gillnetting in 1979 revealed no fish. No other evidence of survival was noted. As a result, the renovation was judged to have achieved a complete kill.

In other situations, it may be impossible to remove as large a percentage of the population $(97 \%)$ as we did. To test the effectiveness of the
Leslie method, had fewer days been fished and a lower percentage of the population removed, we retroactively estimated population size sequentially for each sampling day after the third (Table 1). Point estimates became rather close soon after trapping began, but the upper $95 \%$ confidence limit did not fall within $50 \%$ of the point estimate until April 2, by which time $90 \%$ of the population had been removed. According to Zippin (1956), estimates should have been very good by March 30 or 31 , based on the percentages of the population removed (68 and $78 \%$, respectively). In our case, a high removal rate and variable catches in the first 3 days were likely causes of the departure from Zippin's prediction.

A problem common to most estimation procedures based on removal is a nonlinearly declining catch rate. This results from variation in catchability or low removal rates, which reduce correlation coefficients. In some cases, this problem can be lessened if the regression analysis is restricted to segments of the data that show a steadily declining catch rate (Hatcher 1962). For example, a regression based on our catch from March 31 to April 5 yields a Leslie estimate of 2,010 northern pike $(95 \%$ confidence interval: $1,780-2,380$ ). Added to the harvest from March 28 to 30 the estimate becomes $6,280(6,060-6,660)$. This estimate is just as accurate as that based on the full 9-day regression, but more precise.

\section{References}

HATCHER, R. M. 1962. The estimation of channel catfish (Ictalurus punctatus Rafinesque) populations in farm ponds from catch statistics. Proceedings of the Annual Conference of Southeast Game and Fish Commissioners 16:270-276. 
JoHnson, M. G. 1965. Estimates of fish populations in warmwater streams by the removal method. Transactions of the American Fisheries Society 94:350-357.

MCCarraher, D. B. 1977. Nebraska's sandhills lakes. Nebraska Game and Parks Commission, Lincoln, Nebraska, USA.

OMAND, D. N. 1951. A study of populations of fish based on catch-effort statistics. Journal of Wildlife Management 15:88-98.

RiCKER, W. E. 1975. Computation and interpreta- tion of biological statistics of fish populations. Fisheries Research Board of Canada Bulletin 191.

Von Geldern, C. E. 1961. Application of the DeLury method in determining the harvest of stocked catchable-sized trout. Transactions of the American Fisheries Society 90:259-263.

ZIPPIN, C. 1956. An evaluation of the removal method of estimating animal populations. Biometrics 12:163-189. 